\title{
Conservation work at Petra: What had been done and what is needed
}

${ }^{a}$ Fadi Bala'awi*, ${ }^{\text {a } Y a h y a ~ A l s h a w a b k e h, ~}$ ${ }^{\text {a }}$ Mohammed Waheeb and ${ }^{\mathrm{a}}$ Firas Alawneh

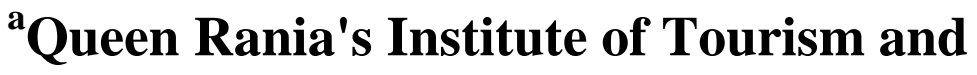
Heritage, Hashemite University Zarqa-Jordan 


\section{Introduction}

Conservation of archaeological sites is one of the most contradictory topics in heritage protection. This could be related to the complexity and sensitivity of conservation issues as well as the wide range of groups who are interested in these issues. In addition, conservation of the archaeological sites should be interdependent work, which takes into consideration any previous work before starting a new project. The discussion and evaluation of the previous conservation work on a site is without any doubt an essential and primary task, since it gives the conservator the areas where the previous work had failed or the areas that need to be studied more.

One of the most important sites in Jordan is the Red Rose City, Petra. In this ancient city a considerable amount of conservation work has been carried out. Some of these works failed totally, others affected the authenticity of the city, and others were successful. In these days the deterioration and the decay of the unique monuments in Petra are increasing at noticeable levels. In order to demonstrate the main conservation work that needs to be carried out in Petra monuments, the 
current research propose to discuss and evaluate a selective group of the previous conservation work that had been carried out in the archeological city of Petra.

The paper will start with a brief description for Petra location, historical background, economic importance and inhabitances. Then, the main purpose and methodology of this study will be demonstrated and discussed. This will be followed with a summary of the main previous conservation that had been carried out at the city.

The paper will extend to discuss and evaluate the historical, structural and current condition of Petra monuments. Three recent conservation projects at the city of Petra will be discussed and evaluated in more details. This includes the German- Jordanian Project in the Restoration of the Rockcut Tomb Facades (19932000), the conservation project in the Byzantine Church by the American Centre of Oriental Research (ACOR) (1990-2001), and the conservation work of the Great Temple by Brown University (1993-till now). Finally, the conclusion will summarize the current survey result and propose what is really needed for the conservation and protection of the World Heritage Site of Petra. 


\section{Petra: The site}

\subsection{General}

Jordan lies at the heart of one of the most historically important and intellectually intriguing regions on earth. The Kingdom has more than 10,000 known archaeological sites with many yet to be discovered. One of the most famous sites in Jordan is the World Heritage Site of Petra. The archaeological city of Petra with its 2000 sandstone rock cut façades is considered by many to be the eighth wonder of the world. It is a Nabatean city that was hewed into coloured sandstone and Limestone Mountains. The Nabateans were nomadic Arabic people who ranged between Syria and Arabia from the $7^{\text {th }}$ century before the Christian era to the 2nd century after the Christian (Burgen 2000). Petra in Greek means the rock or the stone, and it is also repeatedly mentioned in the Bible as "Sela", which means the rock in Hebrew (Bourbon 1999). However, some authors such as Naoum (1993) said the name of Petra had an Arabic origin from the world "batara", which means cut or hew. Also, it used to be called Wadi Mousa or the Valley of Mousa, which is now the modern village around the ancient city. Additionally, 
the city is famous for its name The Red Rose City, because of its wonderful sandstone colours. Petra is the biggest tourist attraction in Jordan; however the city suffers from weathering and erosion problems, both natural and human in origin.

\subsection{The location}

The city of Petra lies hidden in the Desert Mountains in the southern part of Jordan, half way between the Dead Sea and the Gulf of Aqaba. It is $255 \mathrm{~km}$ away from Amman (the capital of Jordan) (Figure.1). The international coordinates for the city are $35^{\circ} 25^{\prime} \mathrm{E}-{35^{\circ}}^{\circ}$ $28^{\prime} \mathrm{E}$ and $30^{\circ} 19^{\prime} \mathrm{N}-3^{\circ} \mathbf{2 1}^{\prime} \mathrm{N}$. The archaeological city of Petra occupies about $15 \mathrm{~km}^{2}$ and is 900 to $1500 \mathrm{~m}$ above sea level.

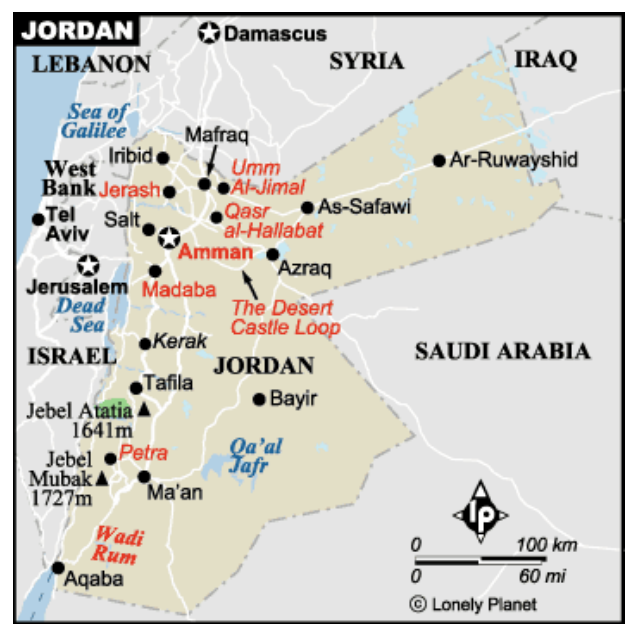

Figure 1: Map of Jordan and its main archaeological sites.

(Lonely Planet 2004) 


\subsection{The climate}

According to a report by the Jordan Meteorological Department (JMD 2003), the climate in Jordan is predominantly Mediterranean. This means hot, dry summers and cool, wet winters with two short transitional periods in autumn and spring. More than $80 \%$ of Jordanian land is considered to be arid.

Average rainfall ranges from $600 \mathrm{~mm} / \mathrm{year}$ in the north to less than $50 \mathrm{~mm} / \mathrm{year}$ in the south. The rainy season is between October and May. Eighty percent of the annual rainfall occurs from December to March.

The study area, Petra, is a rather semi-arid, steppelike region in which small plants survive in winter and spring. Generally, dry hot summers and relatively cold dry winters characterise it.

\subsection{The economic context of Petra}

As well as being of vital historical value, Petra has also been of the most crucial economic value both for the Nabataeans and Jordanians. For the Nabataeans, Petra was not only the capital of their Kingdom but also the central position of their trade. For example, communications between the Hejaz and Mediterranean ports usually used Petra as a transit point due to its 
strategic position on the ancient trade routes. In addition, the natural defensible location of Petra made the trade easier and safer. According to Bienkowski (1992), the great civilization in Petra was related directly to the economic profits from trade. It is certainly true that the trade of the Nabataeans with many nations, and especially the trade with Roman Empire, improved their economic situation, which gave them the money to construct their Eighth Wonder of the World.

In addition, Petra is a crucial feature of the Jordanian economy. For instance, in 1998 it generated about 755 million US dollars, which accounted for about four percent of the Gross National Product (GNP) (ACOR 1999). Moreover, job opportunities were increased after tourist constructions in Petra. For example, three years ago, the Jordanian Government constructed a huge tourist centre in Petra, and as a result, a considerable number of job opportunities became available for the Jordanian people, and especially for the local communities.

It is certainly true that this astounding site awarded Jordan not only the economic profits from tourism 
activities, but also international popularity in a highly competitive tourist market.

\subsection{The Monuments of Petra}

Petra monuments and ruins are unique in their architecture, distribution, and variety as well as their durability. To understand the general situation of Petra monuments, which is the core elements in understanding the conservation work in Petra, it essential to understand the monument history, structure and importance. It is worthwhile to remember that the archaeological site in Petra contains more than 2000 monument and only three monuments which had a major conservation work will be presented at this paper .

\subsubsection{Tomb 825}

Tomb 825 (Figure2, A) according to Brunnow's classification and sometimes it is known as The Tomb of the 17 Graves, since it has fourteen graves cut into its floor and three more in large rectangular recess in the back wall (Khouri 1986). Shaer and Aslan 2000 reported that this tomb is consisted of two sets of large steps, a cavetto cornice, an attic storey and a classical cornice. The importance of this tomb can be 
summarized in its typical Nabateans architecture style, representatively to the Nabateans family tomb and in the conservation work that took place in this tomb.

\subsubsection{The Byzantine Church}

It had been discovered by an American Archaeologist called Kenneth Russell 1973, however, the first excavation stage started on the 30 of May 1992 and the last stage finished on the 28 of July 1996. The Byzantine Church was built in the $6^{\text {th }}$ century by the Christen from. The church according to many writers such Bourbon (1999) and Vivekanand (1995) is a tripartite basilica: a long central nave and two side aisles which all ends in inscripted apse. Amazing mosaics that describe the four seasons of the year cover the central floor of the church, while the northern and eastern sides of the church had a mosaic floor with a wide range of wonderful animals figures (Figure 2,B). A partially destroyed baptistery with four limestone columns can be noticed in the west side of the church. On December 1993, discovering a group of Papyrus archives (scrolls) in on chamber adjacent to the church (Fiema 1993) appeared another surprise. It is certainly true that the Byzantine Church is one of the most exacting ruins in Petra not only because of its floor mosaic, but also for 
its importance in the history of Christianity in that area.

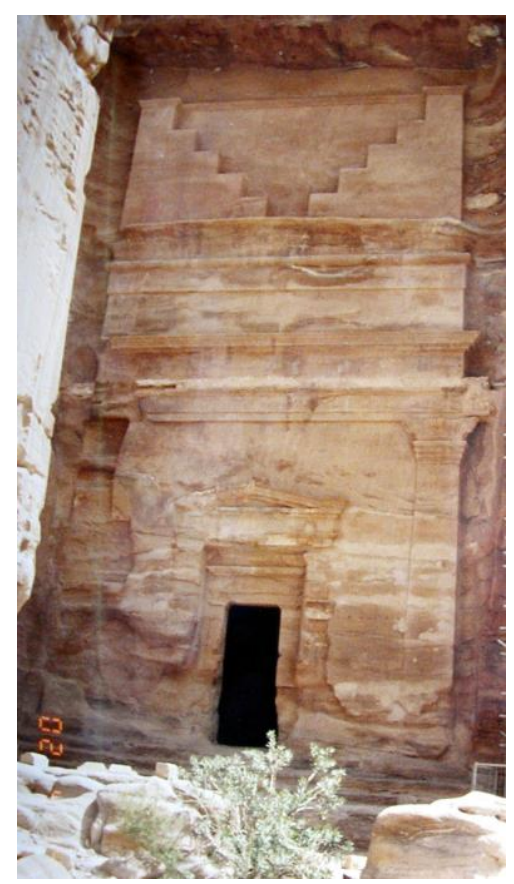

A

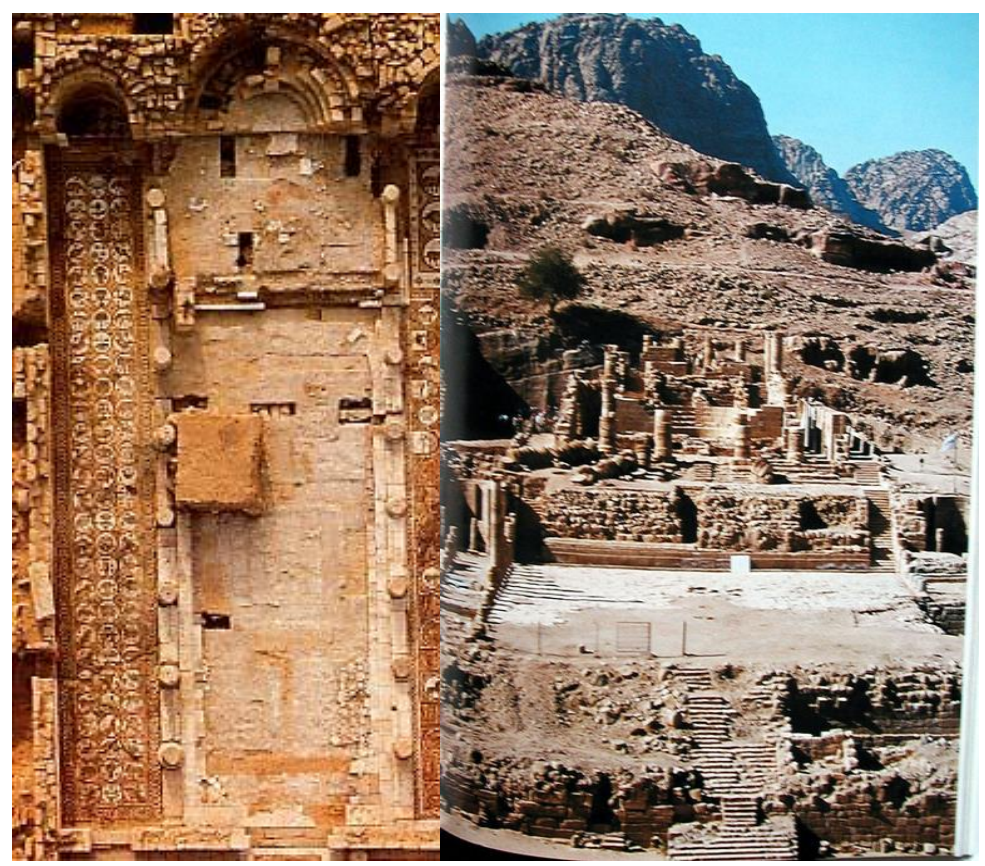

B

C

Figure (2) The three case study monuments

A: Tomb 825, B: Byzantine Church, Source: ACOR (2000)

and C: The Great Temple, Source: Taylor (2001)

\subsubsection{The Great Temple}

Brown University (1993-2000) excavated the Great Temple (Figure 2, C) under the direction of Martha harp Joukowsky. The temple is about 105 feet $(35 \mathrm{~m})$ 
east-west and 127.5 feet $(42.5 \mathrm{~m})$ length, and composed mainly of monumental entryway or what it is called "Propylaeum", Lower Temenos, East and West Exedra which lead to the Upper Temenos-the scared enclosure for the temple proper (Joukowsky 1999). The temple was constructed for he Nabateans god Al Uzza. The floor frieze element that had been founded during Brown University excavation in the temple suggested that the temple was constructed in the last quarter of the first century BCE and a huge enlargement took place on the temple the first century CE. Bourbon 1999 reported that the temple was collapsed after an earthquake around the $6^{\text {th }}$ century.

3. Summary of the main conservation Project in Petra

The conservation of Petra monuments is a very old dilemma in Jordan. Unfortunately, most of conservation projects in the city were a by-product of tourism development. In the following section some of the important conservation project in Petra will be presented and evaluated briefly.

One of the earliest conservation projects in Petra is the repaired of the third pillar of the Treasury building 
in 1958. United State Agency for International development (USAID) founded this project. The project succeeds in restore and enhances the view of the most attractive monument in Petra (The Tesuaery or what is called in Arabic Al Khazneh) by reconstruct the third column of the monument. However, it is hardly to notice this column from the others columns, especially if you did not know the conservation background of the site. Also, unfortunately, in the site there is no signs or boards that describe the conservation work in this site, or even just a brief mention of it. It is worthwhile to remember that the reconstitution of this column took place in 1958, which is before the Venice Charter 1964 or the Nara document on authenticity 1994. However, one can say that this project adhered the principles of Athens Charter for restoration of historical Monuments (1931) that emphasized in the aesthetic appearance of the monuments. From my point of view, the conserving of third column of the treasury is a part of the site history in these days and the project achievements should be appreciate, since the work had been documented and the its work carried out with highly accuracy. In contrast, the project did not take in consideration many modern conservation principles 
such as the minim intervention and the authenticity of the place.

During the excavation of the main theatre in the early 1960s, a few conservation work took place on the site. During the late 1960s, the USAID provided funding to complete a master plan to guide future development of Petra site (United State Support for the World Heritage Sites 2001). The plan identify the flooding in the Siq area as a major problem on the city, as a consequence it had been recommend to reconstruct the Nabatens dam in the entrance of the site. The restoration of the Nabateans dam was not only a solution for a problem exist, but extend to cover a wider issues in presenting the intelligently of the Nabatens engineers, which aid another significant to the place. In addition, during the excavation campaigns in the temple of the Winged Lion (1974-1990) a sequence of conservation work took place in the excavated areas. The Department of Antiquity -Jordan carried out a clearance campaign in Urn Tomb in 1975.

In 1981 a restoration campaign was held the Department of Antiquity in the city. The work of this campaign includes the Siq clearance from the accumulated debris, the clearance of the entrance to 
tomb 64, the restoration of the city gate, clearance in Qasr Al Bint, and the restoration of some Fresco in the rock carved cave with the co-operation with the National Museum of Madrid (Zayadine 1981). Another excavation and restoration campaign was resumed in the Qasr Al Bint from the $3^{\text {rd }}$ of October to December $20^{\text {th }}, 1983$ and in May 1984 (Zayadine 1986). In 1991, and in order to compensate the total absence of income from tourism, which affect more than $\mathbf{3 0 0}$ family from the local community, a clearance and excavation campaign was carried out in Petra by Petra National Trust $^{1}$ (Zayadine and Farajat 1991). Moreover, in 1993 a Jordanian - German group started a very important conservation project in the rockcut facades in the city. Brown University carried out another important excavation and conservation project in the Great Temple in 1993 and the project still carrying on. Beside that, and through USAID funding, a second master plan for Petra and the surrounding region was completed in 1994. Unfortunately, this plan does not put in work. In 1993 the American Centre for Oriental Research

\footnotetext{
${ }^{1}$ Petra National Trust: “A society founded by a group of Jordanian in 1989 to bring together people in Jordan and abroad who are committed to a collective international effort to safeguard Petra's unique physical and Human heritage" (Zayadine and Farajat 1991)
} 
(ACOR) started a conservation project in the Byzantine Church.

Beside that, in 1994 the ACOR with the co-operation Helsinki University started a conservation project in some papyri scrolls that had been founded in the Byzantine Church. In addition, a Swiss-Liechtenstein excavation group carried out a restoration and consolidation campaign in the zanture area in 1994. Fitzner and Heinrichs evaluated the weathering damage monuments carved from rock in the city (1996-1999). In 1999 Paradise carried out another weathering analysis research in the sandstone of the Theatre. It is worthwhile that UNSECO with the co-operation the Jordanian government and a wide range of archaeological expertise complete a new management plan for Petra area, which include a conservation plan for the city, but this plan dos not published yet.

To conclude, one can say the conservation work in Petra in concerning a wide range of authorities inside and outside Jordan. The evaluation of all of these projects is very important to demonstrate the future needs, however, and due to the limitation of this paper, the author proposed to discuss and evaluate three main 
conservation project in the following sections and they are:

- The German- Jordanian preservation Project (1993-2000).

- The Great Temple Project (1993- till now).

- The Byzantine Church Project (1993-2000).

The chosen of these projects is related not only not to the practical conservation achievements, but also to their importance in establishing new conservation concepts in the city.

4. Petra Stone Preservation Project (JordanianGerman Conservation Project) [1993-2000]

A Jordanian-German group carried out a conservation project in the rockcut façades in Petra from 1993 till 2000, which is certainly one of the most unique and valuable conservation projects in Jordan. This is related not only to its successful practical work in stone conservation in the city, but also to the wider issues and principles the project tried to establish in the conservation field in a country which really had no experience in these basic and essential issues. 
The establishment of this stone preservation project in Petra, which became known later as the JordanianGerman Project for the Establishment of Conservation and Restoration Centre in Petra (CARCIP), could be considered as a special start in the conservation field in Jordan.

According to Fisher (2000), the main goal of the (CARCIP) project was to implement and institutionalize internationally accepted conservation and restoration practice and procedures in Jordan.

The establishment of specialized and fully equipped conservation and restoration centre in Petra was the starting point for this tremendous goal. The centre had to be able to plan, support, supervise and execute entire conservation and restoration projects in Petra at the end of this project (Greipal 2000). It is important to notice that the project plan mentioned that the Centre should be operated and managed by Jordanian hands at the end of the project.

\subsection{Project Procedures}

The project was carried out by the German Technical Cooperation (GTZ) (1993-2000) through a grant from the Federal Ministry for Economic 
Cooperation and Development (BMZ)-Germany, in cooperation with the Department of Antiquity- Jordan (DOA), the Restoration Department at the Bavarian State Department of Historical Monuments -Germany (BLfD), the Institute of Archaeology and Anthropology at Yarmouk University-Jordan (IAA), the Hashemite University-Jordan and the Higher Council for Science and Technology-Jordan (HCST).

The project was divided into three main phases: -

- The buildup phase: - this phase included the training programmers to provide staff with necessary the skills in conservation work as well as the supply and installation of the centre's tools and equipment to be capable of running the conservation work.

From my point of view, the combination of the installation of the centre with the needed equipment, and running of the training programs for the staff was a wise design. This is related to the fact that most development programmers stopped totally after the end of their project due to the lack of skilled local people who were able to run these projects.

- Execution phase: -the phase includes the practical conservation work, i.e. where the façades of the monuments will be restored. The purpose of this stage is 
not only to restore certain façades in Petra, but also to build experience in the local staff. For my view, the building of such experience in the local community will create a very strong base for comprehensive conservation work, where traditional knowledge is accompanied by modern and scientific knowledge.

- Consolidation phase: - it is the stage of securing the operation of the centre in the future. One can say that this stage is one of the most difficult stages, since it is a transitional stage, where responsibility is moved towards the local staff. Universities in Jordan, such as Hashemite and Yarmouk University, will have a crucial role in this stage, by providing the centre with qualified people who are capable of securing the running of the centre as well as its improvement. It worthwhile mentioning that both universities (Yarmouk and Hashemite) have started conservation programmers in order to secure the success of the continuity of this stage and the following stages.

To conclude, one can say the procedures of the project were comprehensive and unified, since they consider all issues related to the project gradually and systematically. 


\subsection{The Project's Achievements and Challenges}

As mentioned earlier, the tasks the project aims to achieve are quite complicated and will take an enormous time and effort to be achieved. However, the project in its first six years (1993-1999) is, by and large, gone in the right direction. According to project procedures, the duration of the project is about nine years, three years for each step of its three previously mentioned steps. The project's achievements in its first six years (i.e. in the first two stages of the project) were enormous and valuable. First of all, most of the technical issues were completed. This includes the setting of the essential tools and structures for the coming conservation work, for instance, metal scaffolding, hammers, photographic equipment and truck with hydraulic crane. According to Fischer (2000), the necessary support structure has been successfully established, especially due to the important backing from BLfD. Secondly, the conservation Laboratory in Yarmouk University was upgraded in order to improve field testing and the evaluation of the materials and methods of conservation in Petra's monuments (Fisher 2000). Moreover, a database centre for field image analysis and data collection have been 
established in the Hashemite University. Akasheh (2000) mentioned that with the construction of such comprehensive centre, its activities of documentation extend beyond the monuments themselves to all aspects related to Petra, and will be an extremely useful source of information needed for conservation work in Petra. In addition, one of the most important achievements of the project is the development of the concepts of conservation and restoration, not only in Petra but also in the whole country (Fisher 2000). The author believed that the CARCIP project elaborated the conservation and restoration aspects to international standards not only to the people who are interested in these topics, but more importantly to the local community. On the practical side, a very important success was attained, through the restoration of a complete tomb facade (Tomb 825). The restoration of this tomb is considered as extraordinary work, even though it took time, stopped many times and was done mainly by the German experts. This is related to the fact the this practical work is different from the ordinary restoration work in the city, since it was done within international conservation principles, provided the local community with considerable field work experience and 
set up the bases for the coming conservation work). Besides that, the project started research links in conservation work with different campaigns. For example, it is reported that a research link has been agreed with University College London to explore and address the obvious problem of salt contamination in the monuments and its effects on the deterioration process (Fisher 2000).

On the other hand, a wide range of challenges face the project. First and most important, is the funding problem. The CARCIP project, like many development programmes in developing countries, has a problem of bringing on funding resources after the end of the foreign support. Operating and developing the centre is more important than establishing it. One of the proposed solutions is to establish a trust fund (Fisher 2000). Secondly, the process of project institutionalization (i.e. transferring into a nongovernment organisation [NGO]) still needs a lot of work. In my view, even though I agreed with the fact that an NGO has more flexibility and independence in its designs, it is really difficult for such a project in a country like Jordan to become completely independent from the governmental side. Other challenges include 
doubts about the continuity of creating a skilled generation who will be able to operate the centre for the coming times.

In summary, the achievements of the CARCIP project are really valuable in the conservation field in Petra. The introduction of essential conservation tools, the creation \& development of laboratories, research field linking with renowned campaigns, training of the local community and the restoration of a complete tomb façade are the project's main achievements. However, project institutionalization, funding

\section{The Byzantine Church Project}

The American Centre of Oriental Research (ACOR) and an American archaeologist Kenneth. W. Russell started the work of realizing a huge excavation and conservation project in the Byzantine Church of Petra in 1990. The Petra Church Project is an important event in Petra history not only for its revealing a blank period in that area (the Byzantine period), but also for its comprehensive conservation goals and the systematical work strategy it's adhere to achieve these goals. The main goals of the Petra Church Project can be summarized in the following points: 
- To excavate the whole complex of the church.

- To preserve the excavated structure.

- To establish secure environment for the expected mosaic floors in the church (i.e. to construct a preventive shelter in the site.

-To present the church to the public.

The project was carried out into four different excavation phases:

- First phase (May 1992- March 1993): - In this phase, the main church and its mosaic were uncovered and in situ conservation works were taken during and immediately after excavation. The team of this phase composed of 25 archaeologist, 3 conservators, artist, surveyors and photographers.

-Second Phase (September 1993- April 1994): - the excavation and in situ conservation work continued in this phase. The most remarkable event in this stage was the discovering of 152 papyrus scrolls in one room the church.

-Third Phase (Mid of September 1996- May 1997): This phase was devoted mainly to prepare and install the preventive shelter. 
-Final Phase (spring 1998-July 1998): - This stage was set up to continue the conservation work in the church mosaic and to configure the place in order to open it to the public.

The Petra church project was completely aware of the international conservation approaches. So, groups of preventive conservation measure were taken before the excavation stage. In Petra Church Project, the previous observation before the excavation, which carried out mainly by $K$. Russell, revealed that the structure of the church is very fragile and required an immediately intervention action. Moreover, due to field observation by Dr. K. Russell in 1990, a cross-section of the mosaic was founded protruding from the soil. Beside that, thousands of glass tesserae was founded on the surface, which indicated there were once mosaic in the church walls. The results of these observations were completely considered on the planning phase of the project. In addition, the project planners were conscious about the importance of establishing a permanent shelter on the site, so a considerable part of the project budget was kept for the establishment of the shelter (Russell 1992). 
The second stage of conservation work in this project carried out during the excavation of the church complex. This includes the conservation of the wall plaster, masonry and mosaic. The conservation work that took place after the excavation was intensive and variable. After excavation, the conservation stage includes:

- The Restoration of Church Walls: The uncovered interior walls were found in situ to a height of $1.5 \mathrm{~m}$ to 3.0m (Fiema, Kanelleopoulos, Waliszewski, \& Schick 2001). The decision was to restore all of the walls to a height of $3.0 \mathrm{~m}$ by adding three or four courses of stone on the top of the existing walls. Even, the stone course that had been used were from the site itself and the new stones were distinguished from the existing one by inserting a plastic mesh screen between them, from my point of view there was maximum intervention in this work. This does not mean that what had been done is wrong, but I mean that intervention was intensive and I prefer to preserve what had been found in situ without any adding. However, it should be kept in mind that the main aim of the Petra Project is to develop the tourist industry in the country, so the aesthetic appearance was crucial in the conservation process. 
- The Conservation and Restoration of the Mosaic:

One of the biggest dilemmas in this project was the conservation of the mosaic after the excavation. The first step was the removing of the $10 \mathrm{~cm}$ soil layer above the mosaic by the conservator. Secondly, the condition of the mosaic was assisted. After the assessment of the mosaic condition, the cleaning stage started. Handpump water sprayers with toothbrushes and sponges were used. In some areas, a scalpel with poultices of ammonium carbonate and sodium EDTA 9 was used to remove the mineral encrustation, which covered a large area of the mosaic (Roby 1995). The later stage was the in situ consolidation of the deteriorated tesserae, which mainly related to the loss of humidity due to the exposure of mosaic surface, salt crystallization on surface or both together.

- Restoration and reconstruction of the Church Columns and Capitals: - The restoration process of the columns and capitals was difficult due to the difficulty of determine the original location of most of these structures. However, the decision was taken to restore all of the columns (16 columns). The restoration carried out by following the principle of restoration in 
the manner of construction, which is uncertain and in other cases a randomly restoration were carried out.

- The constructing of the primary shelter: - The most significant and complicated conservation approach in this project was the construction of a proper and primary shelter on the site. From the planning stage of the project, it has been noted the uncovering of the church mosaic will imply a construction of primary shelter to prevent these sensitive and unique pieces of art from the deterioration as result of reaction with water and sun. However, the shelter impact on the site context, cost, reversibility, minimum intervention, simplicity in installation, natural lighting \& ventilation, flexibility \& expandability, security and Environmental control were all a crucial approaches the shelter design should considered (Fiema, Kanelleopoulos, Waliszewski, \& Schick 2001). Consequently, and due to the site exclusiveness, which required a shelter to cover the whole site with a minimum impact, there were two choices: building with massive foundation, or a modern but expensive technology, which known as space frame (Fiema, Kanelleopoulos, Waliszewski, \& Schick 2001, and ACOR 2000). The project committee was completely aware of the site sensitivity and exclusivity, 
so the space frame technology was chosen. The shelter rides on only on six columns completely reversible ones. Moreover, the canopy consists of an extruded aluminum with a vinyl covering (ACOR 2000). It is worthwhile to mention that the installation process take 5 weeks only. The author believes that shelter design was really satisfactory in different aspects. Firstly, it's minimum intervention approach. . Secondly, its reversibility and flexibility, since it is a huge change to organelle context of the site. Burra charter, article 15.2, recommend that change reduce cultural significant should be reversible, and be reversed when circumstance permit. Moreover, the shelter design succeeded in providing acceptable natural ventilation and lighting schemes. In addition, since the shelter dose not produced a green house heat affect as it the case in some shelter design that used a plastic translucent. In other word the environment inside the shelter are more or less stable. Finally, the shelter does not affect the visitors enjoyment of the site, in contrast, it add an educational value of the site. For instance, it reflects the original size of the site, its importance and finally the conservation efforts that had been done to protect such an important cultural heritage site. On the other hand, 
there are some points the points in the shelter design project the author does not agree with. Firstly, the shelter is the only modern structure in the city, which is in my point of view add a new context to the site, which should be avoided as much as possible. In another word, the shelter design did not looks compatible with the surrounding environment. Stanley Price (1997) mentioned that the type of shelter solution on archaeological sites should be aesthetically compatible with the environment of the ancient remains. Beside that, the maintenance of such structure is quite expensive and required a foreign expertise, which may not be available in the future, since the project is completely carried out through a foreign foundations. Jerome (1995) reported the shelter construction on archaeological sites, especially in the developing countries, must be carried out in low cost and dose not required a higher maintenance budget.

In Short, it certainly true that the construction of Petra Church shelter was a crucial intervention to ensure a longer life for a wonderful property and to minimize the environmental impact on a unique and sensitive structure. The shelter design was generally aware of the international approaches in such 
intervention. Its reversibility, flexibility, safety to the site component and its control to internal environment were the main advantages. In contrast, from the author point of view, the shelter design did not fit with city context and it maintenance could be a future problem.

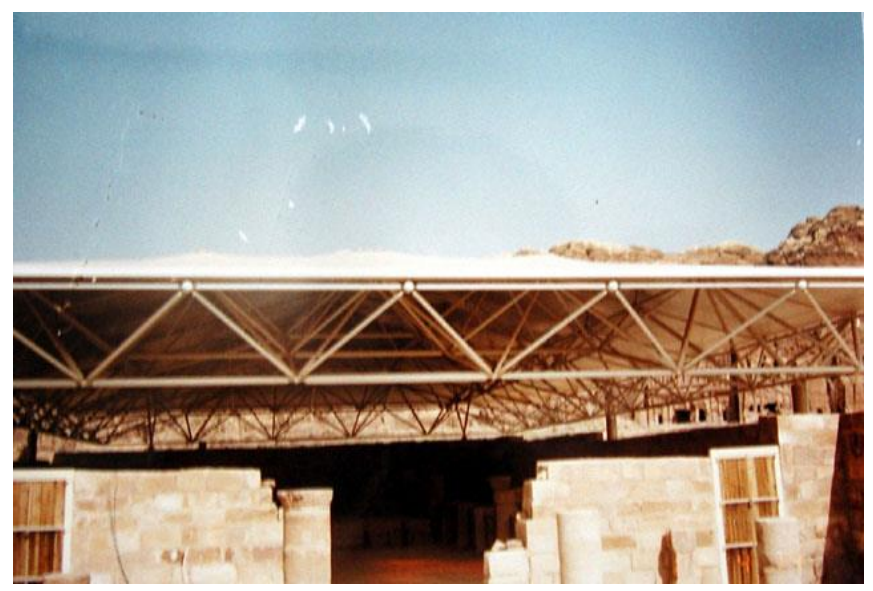

5. A Summary of the main Conservation Researches in Petra

In order to conclude the discussion of the conservation work that had been done in Petra, a summary of the main conservation research that carried out in the city will be presented briefly. It is worthwhile remembering that the presentation of these researches will include research topic and results not its technical part. 
5. 1 The Evaluation of Weathering Damages on Monuments Carved from Rock in Petra-Jordan (Fitzner and Heinrichs 1996-1999)

For better understanding of the stone weathering in Petra and the damage to its monuments, a research project were carried out by B. Fitzner and K. Heinrichs between 1996 and 1999. The project aimed to document and evaluate the actual state of the monument carved from the bedrock, approach the results in weathering model and finally evaluate the survey results for the monuments preservation needs (Fitzner and Heinrichs 1998). To achieve the above goals 22 monuments were selected. It is should be noted that the selection of monument considered the variety of stone type and characteristic as well as the feedback from the Jordanian scientist (Fitzner and Heinrichs 1998). The project investigation program consisted from in situ and laboratory tests. The fieldwork consisted of the lithotypes description, monument description, monument mapping, measurement sampling and photodocumentation. On the other hand, the laboratory work compromised mainly of petrographical classification, characterization of stone properties, chronology of stone alteration, identification of the 
weathering products and characterization of weathering behavior of stone properties (Fitzner \& Heinrichs 1998). The research project achievements according to Heinrichs \& Fitzner (2000), Heinrichs \& Fitzner (1999) and Fitzner \& Heinrichs (1998) can be summarized as follows:

1-Producing an accurate subdivision of the monument lithotypes.

2-Lithographic mapping of the monuments with quantitative evaluation of the lithotypes.

3-Mapping and quantitative evaluation of weathering form for the monuments by using a phenomenological method, which had been devolved by the project authors and a special computer program (for more details see Fitzner and Heinrichs 1998 and Fitzner, Heinrichs and Kownatazki 1997).

4-Estimating and mapping of the weathering rates on the examined monuments.

5-Producing a chronological sequence of the weathering forms, which is a very important for understanding the development of weathering damage.

6-A detailed evaluation of the relation between the different weathering forms. 
7-The producing of an exposure characteristics maps for the tested monuments.

To conclude, one can say that the above research project is a comprehensive study of the weathering forms in Petra monuments, which is the primary stage in conserving them.

In my view, problem identification is the most important stage in the conservation work, therefore the demonstrating and evaluation of the weathering form in Petra monument is an essential work that should be carried before taken any conservation intervention.

5.2 Analysis of Sandstone Weathering of the Roman Theater in Petra, Jordan (T. Paradise 1995).

In 1995, T. Paradise from Hawaii and Hilo University started a conservation research project in the main theatre in Petra. The project aims to understand the theoretical weathering principles in the theatre in order to assist the future chemical solution for the weathering problem (Paradise1995). The research based on the determination of the sandstone weathered and eroded since the data of its construction by the determination of 
the pre-weathered dresses sandstone surface11 and correlate with the actual state. The research conclude that both the variation in rock matrix chemistry as well as the aspect and its related annual solar flux were the main factors that influence the deterioration of sandstone surface in the theatre (Paradise 1999).

From the above study, one can observe the vast challenge in the conservation issues in a site such as Petra, since the factors that influenced the deteoriation of the city monuments are numerous and varied from place to another even in the same monument.

5. 3 Laboratory Evaluation of Various Types of Mortars for the conservation of Qasr Al- Bint Monument, Petra-Jordan. (Al-Saad and AbdelHalim 2001)

After the recognition of the vast damages in Qasr AlBint monument, which results from the using of unsuitable mortar it has been noted that any future conservation work in this monument should be precede by an accurate evaluation of the mortar that will be used on the conservation process. This point was clearly understood by Dr. Zaid Al-Saad from Yarmouk University-Jordan and Dr. Mohammed Abdel-Halim 
from Jordan University of Science and TechnologyJordan, who carried a comprehensive evaluation study in three mortar types that could be used in Qasr Al Bint Monument. The research investigated different mechanical properties for the three proposed mortars such as the compressive strength, the flexural strength, modulus elasticity and water adsorption.

The results of the research conclude that non-of the examined mortar can be used in the whole monument, since each mortar has is positive and negative points. For example, one of the mortars has a low compressive strength and low flexural strength so it could be used for highly weathered and flaky sandstone block; however, it could not be applied to the lowest point on the monument since it has a high affinity of water and so on.

Al Saad carried another research in the evaluation of the effectiveness of a number of stone consolidants in Petra monuments. Similar results to the mortar investigation were obtained in the consolidant research: the nature of Petra monuments and the variety of the it's weathering forms required different consolidant to be used in the conservation of the city. 
From my point of view, the evaluation for the material, which they proposed to be used in an complicated site such as Petra, which has a wide range of weathering forms and rates, is a crucial and fundamental stage prior the application of these materials to the site.

It should be noted that the above research is not the only ones that had been concerned the conservation issues in Petra, but the author believes that they are a representative sample of the main conservation research in the Petra.

5.4. The Chemical and physical evaluation of Petra building materials:

A number of studies had evaluated the physical and chemical properties of Petra stone building materials, which is an wensstial step in any conservation work. For example, The porosity properties of Petra sandstone were studied by many researchers such as Jaser and Bargous (1992), Heinrichs and Fitzner (2000) and Al Naddaf (2002).

The main porosity was in ranges of moderate to high in the Middle Umm Ishrin Sandstone Formation and 
high to very high in the Upper Umm Ishrin Sandstone Formation and the Disi Sandstone Formation.

Jaser and Bargous (1992) examined the permeability of the different sandstone formations of Petra monuments in terms of the coefficient of permeability.

Jaser and Bargous' (1992) data showed that most Petra sandstone permeability measurements ranged between slight (class 4) in Disi, Upper Umm Ishrin and Middle Umm Ishrin Sandstone and very slight (class 5) in Lower Umm Ishrin Sandstone.

Al Naddaf's (2002) carried a comprehensive study on Petra stone materials where the mineralogical content, stone hardness, water absorption capacity, water uptake capacity and stone drilling tests had been carried on a number of samples from Petra building materials.

5.5. Salt Damage at Petra, Jordan: A Study of the Effects of Wind on Salt Distribution and Crystallisation (Bala'awi 2006).

The study had examined the scale of salt damage on the city of Petra. Also, the role of the environmental conditions around the monuments in the activation of salt damage had been evaluated. In particular, the role 
of wind speed in distribution and crystallization of salt had been explored. The results have shown that wind speed has a significant impact on salt crystallisation and distribution in porous materials, and thus on decay rates, and that fluctuating wind speed enhances salt damage more than steady speeds. In addition, the research has suggested an unexpected relationship between pore structure and the behaviour of salts under different environmental conditions.

The study concluded with recommendations for the conservation of the site of Petra. These include proposals for reducing the salt content of certain monuments and for protection against the effects of wind.

To conclude, one can say that the conservation work and research in Petra a wide range of issues, meanwhile the city and due to its high level of deterioration is still need a enamors effort in both the practical and research approaches in the conservation field.

\section{Petra, the problem}

Most Petra monuments are endangered due to weathering processes (Heinrichs and Fitzner 2000). Fischer (1997) claims that more than $80 \%$ of the 
sandstone façades in Petra have been eroded beyond recognition. It is worth remembering that in 1995 the World Monuments Fund inscribed Petra on its list of 100 Most Endangered Sites (Fitzner and Heinrichs 1998).

6.1. The weathering agents in Petra monuments

Natural processes and human activities as well as lack of maintenance in the ancient city are all involved in the weathering process. The natural causes of weathering are summarised below:

\subsubsection{Tectonic movements (earthquakes)}

According to a UNESCO Report (1992) and Jaser and Barjous (1992), Petra is located in a tectonically active region. Jaser and Barjous (1992) traced three major faults in the area which are:

- The Al Matahan Fault (NE-SW): a regional fault and a branch of the sinistral Al Quwayra Fault system.

- The Wadi Arab Fault: the most important fault in the area (186 $\mathrm{km}$ long and $10 \mathrm{~km}$ deep) running from the Gulf of Aqaba to the Dead Sea. 
- The Abu Ullayqa Fault: run in the same direction as the Al Matahan Fault but with a downturn to the east (Al Naddaf 2002).

Due to the high seismic slip between these faults, the area has suffered a series of serious earthquakes. The monuments of Petra have suffered from a wide range of destructive earthquakes, such as the earthquake of $\mathbf{3 6 3}$ AD that destroyed most of the Theatre, and the earthquake of $747 \mathrm{AD}$ that destroyed most of the monuments in the centre of the city. Generally, statistics showed that an earthquake with a magnitude above 6 on the Richter scale occurs every 100 years or so in the area of Petra (UNESCO Report 1992).

\subsubsection{Water erosion}

As mentioned earlier, the rainfall in Petra is very low, but happens in a very short period. Subsequently, water erosion is a very active agent in such an environment. The Nabatean hydrological systems prove that the Nabateans were very much aware of the water erosion problem in their area; they constructed ceramic pipes along the bedrock and the face of the monuments to protect them from the running water (figure 3). Moreover, the horizontal surfaces were covered with 
multilayered mortar to minimise the effect of running water on these features (Shaer and Aslan 2000).

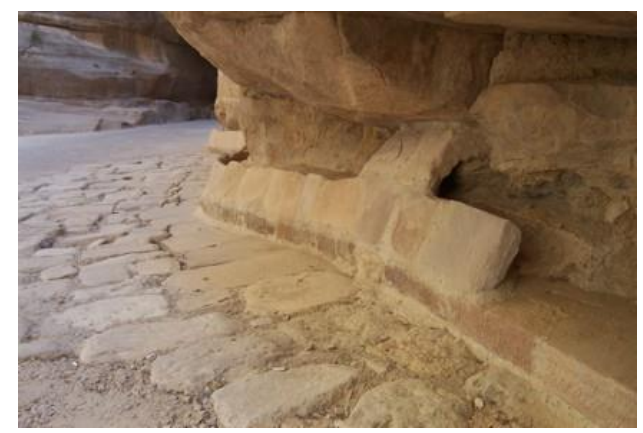

Figure 3: Ceramic pipes at The Siq (main entrance to Petra)

Unfortunately, nowadays, the Nabatean water system is the main cause of water erosion at the site. Joints and cracks that were created by earthquakes as well as the clogging of the Nabatean water channels allow the water to attack the Petra monuments from within and from outside (Fischer 2000).

The American Centre of Oriental Research in Amman (ACOR 1999) reported that the water table in Petra is actually much higher at the dawn of the $21^{\text {st }}$ century than it was at the dawn of the last millennium. The rising of the water table in the area has had a major impact on many other deterioration mechanisms such as the salt crystallisation process and the dissolution or leaching of materials (clay materials, for 
example). These weathering agents will be discussed separately, later in this section.

In short, the water is a major factor in the deterioration process in the city of Petra through flood damage, rainwater, runoff water, and capillary action (and their subsequent effects).

\subsubsection{Wind erosion}

Wind is another important weathering agent for the Petra monuments. Not only does it cause the destruction of monuments due to wind-blown sand (UNESCO Report 1992), but it also enhances other weathering agents, such as salt crystallisation (which is the main scope of this study). The effect of the wind-blown sand is mainly restricted to the lower parts of the monuments (1-2 $\mathrm{m}$ height), as these parts come into contact with sand particles (UNESCO Report 1992).

\subsubsection{Salt crystallisation process}

Salt crystallisation is another, if not the major, weathering agent in Petra monuments. Previous studies, such as Al Naddaf's (2002), showed that drilled samples from the Petra monuments are rich in sodium chloride and calcium sulfate, while the scraped samples were dominated by calcium sulfate. Bala'awi (2006) carried 
out a detailed survey of the salt types, locations and variations within selected monuments in Petra. This research was undertaken in order to examine the role of wind speed in the salt damage process in general, and in the world heritage site of Petra in particular. The study evaluated the role of wind speed in salt crystallisation and distribution. The research presented a detailed monitoring of the microclimate conditions and its role in the salt distribution at selected monuments in Petra, in order to understand the extent and mechanism of salt damage at these monuments. The research developed a salt simulation test that would include the effects of wind. The results have shown that wind speed has a significant impact on salt crystallisation and distribution in porous materials, and thus on decay rates, and that fluctuating wind speed enhances salt damage more than steady speeds.

\subsubsection{Thermal shock}

Due to wide variations in temperature, both daily and seasonally, the monuments in Petra suffer from what is known as 'thermal shock'. This kind of weathering is related to the fact that some minerals expand more than others at high temperatures and contract at low temperatures. A study of the 
temperature variations within a 24-hour cycle in Petra carried out by Fitzner and Heinrichs (1991) showed a difference of $20^{\circ} \mathrm{C}$ in the stone temperature and a difference of $21.1^{\circ} \mathrm{C}$ in the air temperature. In another study of the effect of thermal shock, Paradise (1999) concluded that, as a weathering agent, thermal shock was more effective in calcite-cemented sandstones due to the fact that calcite expands $25 \times 10-6 \mu \mathrm{m} /{ }^{\circ} \mathrm{C}$ parallel to the $\mathrm{C}$-axis and contracts $4.9 \times 106 \mu \mathrm{m} /{ }^{\circ} \mathrm{C}$ normal to the same axis in temperatures between 18 and $50{ }^{\circ} \mathrm{C}$.

The evaluation of the effect of the thermal shock in the mechanical degradation of Petra monuments varies between scholars. Franchi and Pallecchi (1996) concluded that this is the main cause of stone deterioration in the Petra monuments, while others, such as a UNESCO Report (1992) considered it to be a minor cause. In accordance with this, this research supports the idea of the temperature variation having a minor effect and does not consider it to be a main cause of stone deterioration in Petra.

\subsubsection{Biological weathering}

The main biological weathering feature in Petra is the overgrowth of grass in and around the monuments. 
The availability of water allows vegetation to grow on some of the façades, such as the Corinthian Tomb (figure 4), causing considerable destruction of the façades' structure. Insect colonisation in certain monuments also enhances the damage by trapping the water under their nests and blocking its evaporation (Al Naddaf 2002). It should be stated that the impact, if any, of micro-organisms on stone decay in Petra, which could have a significant role in the biological weathering of the monuments, has not been studied.

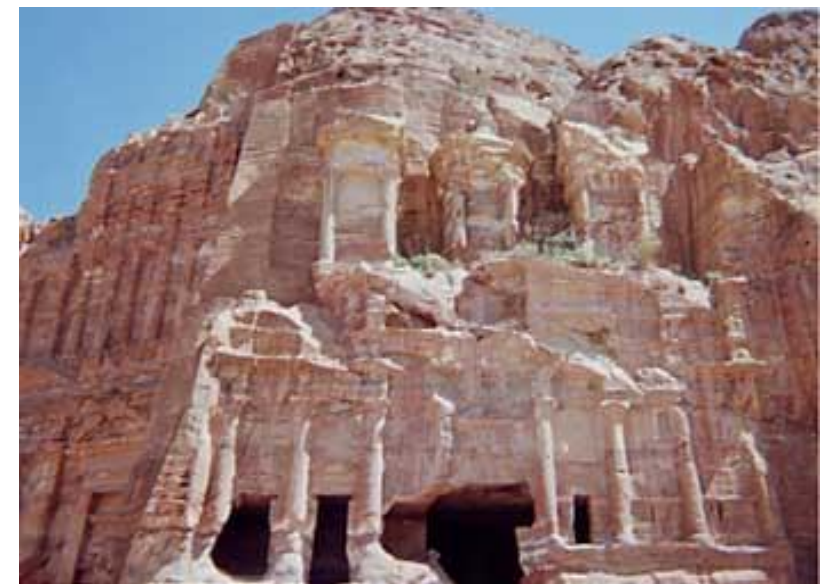

Figure4: The Corinthian Tomb, Petra, Jordan (August 2003)

\subsubsection{Human activities}

The human activities in the city make a considerable contribution to the deterioration of the monuments. Tourism is one of the main destructive factors. For example, Paradise (1999, 355) estimated that '20 
percent of the original masonry marks were visible on the amphitheatre in 1990; however, only 5-10 remained in 1999 due to traffic pollution as well as the type of footwear tourists used at the turn of the century'. Moreover, the uncontrolled urban developments, in and around the archaeological site affect it negatively. This includes the hotel development, as well as the uncontrolled expansion of the villages around the site (Umm Sayhun and Wadi Mousa). This unrestrained development has not only impacted on the aesthetic integrity of the site, but has also increased the rate of pollution in the area.

\subsubsection{Weathering forms in Petra monuments}

The identification, classification, documentation and evaluation of the stone weathering forms are crucial stages prior to the start of any remedial or preventive conservation work. The field survey is the starting point, where the weathering forms are identified. The classification and documentation of these forms are the second step. Due to the many forms of stone decay, various methods are used to classify and document the damage state of the stones. 
Viles et al. (1997) presented a very basic scheme for the classification of the visible deterioration of historical stone monuments. The scheme has three different levels: microscale (cm or less), mesoscale ( $\mathrm{cm}$ to $\mathrm{m}$ ) and macroscale (whole façades, entire monuments).

According to Heinrichs and Fitzner (1998), the term "weathering form" is used for stone deterioration visible at the mesoscale. The Natural Stones and Weathering Group at Aachen University of Technology presented a comprehensive monument-mapping method for in situ studies of weathering damage on natural stone (Fitzner and Heinrichs 2002). This mapping method offered a detailed documentation of all weathering forms, according to the exact type, intensity and distribution. It is based on a comprehensive classification scheme of stone weathering forms, which resulted from the detailed investigation of different monuments around the world (Fitzner, Heinrichs and Kownatzki 1995).

Bala'awi (2002) studied the general condition of the most famous monuments in Petra and indicated the main causes of deterioration in each monument. Table 1 summarises these investigations. 


\begin{tabular}{|c|c|c|}
\hline Monuments & $\begin{array}{l}\text { General } \\
\text { Condition }\end{array}$ & Main Cause of Deterioration \\
\hline Obelisk Tomb & Fair to good & $\begin{array}{c}\text { Winds (eolian weathering) }+ \text { (rain) water }+ \text { salts } \\
\text { crystallisation }\end{array}$ \\
\hline $\begin{array}{c}\text { Bab al-Siq } \\
\text { Triclinium Tomb }\end{array}$ & Fair to poor & $\begin{array}{c}\text { Salts crystallisation }+ \text { winds (eolian weathering) }+ \\
\text { (rain) water }+ \text { horse traffic }+ \text { heavy foot }+ \text { the } \\
\text { nature of the bedrock (soft sandstone) }\end{array}$ \\
\hline The Siq & Fair to good & $\begin{array}{l}\text { Earthquakes + winds + rain + water from the } \\
\text { clogged water channels + tourist activity }+ \\
\text { animals by-product + floods + runoff water }\end{array}$ \\
\hline The Khazneh & Fair to good & $\begin{array}{c}\text { Salts crystallisation + earthquakes + tourist } \\
\text { activity + rain }\end{array}$ \\
\hline The Theatre & Fair to poor & $\begin{array}{l}\text { Variation in the rock matrix chemistry and its } \\
\text { related annual solar flux (Paradise 1999) + rain + } \\
\text { wind + earthquakes }\end{array}$ \\
\hline Palace Tomb & Poor & $\begin{array}{c}\text { Salts crystallisation + runoff water } \\
\text { earthquakes + rain + wind + sun + human } \\
\text { activities }\end{array}$ \\
\hline Corinthian Tomb & Very poor & $\begin{array}{l}\text { Tectonic movements }+ \text { water }+ \text { wind }+ \text { human }+ \\
\text { salt crystallisation }+ \text { runoff water }+ \text { biological } \\
\text { agents (plants growth within the façade) }\end{array}$ \\
\hline $\begin{array}{l}\text { The monuments of } \\
\text { the city centre }\end{array}$ & Poor to fair & $\begin{array}{c}\text { Earthquakes }+\underset{\text { wind }++}{\text { tourist activities }}+\text { rain }+ \text { war }+ \\
\text { wind }\end{array}$ \\
\hline The Deir Tomb & Fair to good & $\begin{array}{l}\text { Earthquakes + tourist activities + rain + war + } \\
\text { wind + runoff water + salt crystallisation }+ \\
\text { biological agents }\end{array}$ \\
\hline
\end{tabular}

Table 1: The general condition of the most important monuments in Petra, their rate of deterioration and the main causes of decay (Bala'awi 2002) 


\section{Conclusion: What is really needed now?}

Based on what had been presented, it can be concluded that the conservation work on the archaeological city of Petra had succeeded in many aspects. At the same time, the study did revel clearly a number of issues that needed to be considered in any future conservation work with the city.

The lack of national conservation policy resulted in many conservation actions with different standard within the same site. Some of the projects focused on the aesthetic part and restoration were highly applied, while the others preferred prevent action dispute its disturbance to the context of the city. The establishment of national conservation policy is a must action and it should be a priority prior carrying out any further conservation projects. The policy should be based on the understanding of the site nature and needs. The policy should also consider the local community involvement in any future work. The policy will reduce the variations between the conservation projects standers at the city of Petra and it will establish a well-defined system for prioritizing the conservation work on the city and how each project should be approached. The system should be simple and based on 
international with special considerations to nature of the city.

Also, the city of Petra did suffer from the large number of scientific research that had been carried out for conservation purposes. Dispute the fact, that all these researches were considerably informative, they were too many and the affect the authenticity of the site. The lack of co-ordination between these researches made some of the work repetitive, were the work in such site should be minimized. The formation of a scientific community with the city of Petra to supervise and coordinate the scientific research is a necessity. The community will be able to minimize the intervention of the scientist on the monument of the city and will have a data base that could provide the core information for any future conservation work.

The study had also showed that the conservation works brought up as immediate a necessity while a large number of excavations are taking place in the city. From the authors' point of view, the excavation should be stop in the city of Petra until the excavated monuments and archaeological remains are conserved.

Moreover, the current study had showed that the local involvement in the conservation projects were 
limited to seasonal conservation work. This had been resulted in a loss of the efforts that had been carried out to train the local and in establishing a national qualified center which could be able to carry out the responsibilities of the conservation work in the city.

In addition, it was quite clear that many of the conservation decision were made on personal judgments. In such unique city the decision should be collaborative and especially in the huge intervention all the stakeholders within the site should be consulted.

It has been also noted, that a little documentation had been provided for the conservation work within the city. The use of a comprehensive documentation system for any conservation work or research should be main concern in any future projects.

All in all, it could be summarized that the scale of conservation work that is needed for the city of Petra is enormous, and the critical review of what had been done before in conservation sector in Petra had revealed how the future work can be approached. The establishing of a national conservation policy in Petra and the monitoring of the scientific research programmers as well as the focus on the conservation of the excavated monuments rather the excavating new 
ones are the main priority of the conservation work in the Nabetean city of Petra. 


\section{References}

Al Naddaf, M., 2002. Weathering Mechanisms: Technical Investigation in Relation to the Conservation of the Sandstone Monuments in Petra, Jordan. Berlin: Mensch and Buch Verlag. 126p.

American Center of Oriental Research (ACOR), 2000, The Petra Church December 1999, Amman: American Center of Oriental Research Publication. [On Line]. Available from:http://www.bearken.com/clients/s/scud/a...Release s/Petra_Chirch/petra_church.htm. \{Accessed on 3 of July 200\}

American Center of Oriental Research (ACOR), 1999, Petra, Jordan: Conservation in an Ancient City, Amman: ACOR Publications. [On Line]. Available from:

http://student.rwu.edu/users/ah1826/ah1826/Petra/PPP ETRA.htm \{Accessed on 3 of December 2001. \{

Akasheh, T., 2000, A Database for Petra. In Kuhlenthal, M., and Fisher, H., 2000. Petra: The Restoration of the Rockcut Tomb Facades, Muchen: Bayerisches Landesamt fur Denkmalpfleg Publication. 
Aslan, Z., and Shaer, M., 2000, Condition Assessment and Execution Plan for the Restoration of Tomb 825 . In Kuhlenthal, M., and Fisher, H., 2000. Petra: The Restoration of the Rockcut Tomb Facades, Muchen: Bayerisches Landesamt fur Denkmalpfleg Publication.

AtlasTours.Net, 1999, Petra-Jordan Sites \& Cities. [OnLine].AvailableFrom:http://www.atlastours.net/jord an/petra.htm. \{Accessed on 12 march 2002\}.

Bala'awi, F., 2006. Salt Damage at Petra, Jordan: A Study of the Effects of Wind on Salt Distribution and Crystallisation. Unpublished PhD Thesis. London: University College London. 646p.

Bala'awi, F., 2002. Conservation Work at Petra: A Critical Review. Unpublished MA Dissertation. London: University College London. 105p.

Bienkowski, P., 1992, Early Edom and Moab The Beginning of the Iron Age in Southern Jordan, Oxford: J.R. Collis Publications.

Bourbon, F., 1999. Petra: Art, History and Itineraries in the Nabatean capital, Italy: White Star S.R.I. Publication.

Burgen, D., 2000. Petra: Match me such a marvel, save in Eastern clime A rose-red city, half as old as 
time.[OnLine].AvailableFrom:

http://www.raingod.com/angus/Gallery/Photos/MiddleE ast/Jordan/Petra.htm \{Accessed on 12 March 200\}.

Fiema, Z., Kanelleopoulos, T., Waliszewski, R., Schick, R., (eds.) 2001, The Petra Church, Amman: American Center of Oriental Research (ACOR) Publications. PP: 439-446 .

Fiema, Z., 1993, The Petra Project. ACOR Newsletter, Vol. 5.1- summer 1993. PP: 1-2 .

Fisher, H., 2000, The German-Jordanian Project for the Establishment of a Conservation and Restoration Center in Petra. In Kuhlenthal, M., and Fisher, H., 2000. Petra: The Restoration of the Rockcut Tomb Facades, Muchen: Bayerisches Landesamt fur Denkmalpfleg Publication

Fischer, H., 1997. Petra's Melting. In American Centre of Oriental Research (ACOR) Report, 1999. Petra, Jordan: Conservation in an Ancient City. Amman: ACOR Publications. pp: 1-15.

Fitzner, B. and Heinrichs, K., 2002. Damage diagnosis on stone monuments -weathering forms, damage categories and damage indices. In Přikryl, R. and Viles, H., (eds.), 2002. Understanding and Managing 
Stone Decay: Proceeding of the International Conference Stone Weathering and Atmospheric Pollution Network (SWAPNET 2001). Prague: Charles University and the Karolinum Press. pp:11-56.

Fitzner, B., and Heinrichs, K., 1998. Evaluation of Weathering damages on Monuments Carved from Rocks in Petra/ Jordan-Research Project 1996-1999. ADAJ (Annual of the Department of Antiquities, Amman- Jordan), Vol. 42. PP: 341-360.

Fitzner, B., and Heinrichs, K., and Kowantzki, R., 1997, Weathering forms at natural stone monumentsclassification, mapping and evaluation, International Journal for restoration of Building and Monuments, Vol. 3. PP: 105-127

Fitzner, B. and Heinrichs, K., 1991. Weathering forms and rock characteristics of historical monuments carved from bedrocks in Petra/Jordan. In Baer, S., Sabbioni, C. and Sors, A., (eds.) 1991. Science, Technology and European Cultural Heritage. Proceeding of the European Symp. Bologna, Italy: ButterworthHeinemann Ltd. pp: 908-911.

Fitzner, B., Heinrichs, K. and Kownataki, R., 1995. Weathering forms - classification and mapping. In 
Denkmalpflege und Naturwissenschaft, 1995. .Natursteinkonservierung. I. Berlin: Ernst and Sohn. pp: 41-88.

Franchi, R. and Pallecchip, P., 1996. The sandstone of Petra: petrography and problems in conservation. In Panacella, P., (ed.), 1996. Preservation and Restoration of Cultural Heritage. Proceedings of the 1995 LCP congress. Montreux, 1995. pp: 679-689.

Greipl, E., 2000, Foreword. In Kuhlenthal, M., and Fisher, H., 2000. Petra: The Restoration of the Rockcut Tomb Facades, Muchen: Bayerisches Landesamt fur Denkmalpfleg Publication.

Heinrichs, K. and Fitzner, B., 2000. Lithotypes of rock-carved monuments in Petra/ Jordan classification and petrographical properties. $A D A J$ (Annual of the Department of Antiquities, Amman Jordan). Vol. 44. pp: 283-312.

Heinrichs, K., and Fitzner, B., 2000. Lithotypes of Rock-Carved Monuments in Petra/ JordanClassification and Petrographical Properties. ADAJ, (Annual of the Department of Antiquities, AmmanJordan) Vol. 44. PP: 283-312 . 
ICOMOS, 1931, The Athens Charter for the Restoration of Historic Monuments. Adopted at the First International Congress of Architects and Technicians of Historic Monuments, Athens, ICOMOS Publication. [On Line]. Available from: www.icomos.org/docs/athens_charter.htm \{Accessed on 15 October 2001\}.

Jaser, D. and Barjous, M., 1992. Geotechnical studies and geological mapping of ancient Petra city. Town Mapping Project, Bulletin 1. Amman: Hashemite Kingdom of Jordan - Ministry of Energy and Mineral Resources - Natural Resources Authority - Geological Directorate - Geological Mapping Division. 60p.

Jerome, P., 1995, Proposed Permant shelter for Building 5 at the Bronze age site of Palaikastro, Crete, Conservation and Management of Archaeological Sites, Vol.1. PP: 35-42.

Jordan Meteorological Department Annual Report (JMD), 2003. Amman: Jordan Meteorological Department Press. 54p.

Joukowsky, M., 1999,The Brown University 1998 Excavations at The Petra Great Temple, ADAJ (Annual 
of the Department of Antiquities, Amman- Jordan), Vol. 43. PP: 195-222.

Khouri, R., 1986. Petra: A Guide to the Capital of Nabateans. London: Longman Publication. 160p.

Naoum, N., 1993, The Castle of Petra. In Cardinal, P, 1993. Petra: the Stone Speaks, London: Aurum Press Avenue.

Paradise, T., 1999. Analysis of Sandstone Weathering of the Roman Theater in Petra, Jordan. ADAJ, Vol. 43. PP: 353-368 .

Paradise, T., 1995. Sandstone Weathering Thresholds in Petra, Jordan. Physical Geography, Vol. 16/3, 205.

Saad, Z., and Abdel-Halim, 2001 , Laboratory Evaluation of Various Types of Mortars for the Conservation of qasr Al-Bint Monument, Petra-Jordan, Engineering Structures, Vol. 23. PP: 926-933.

Shaer, M., and Aslan, Z., 2000, Nabataean Building Techniques with Special Reference to the Architecture of Tomb 825. In Kuhlenthal, M., and Fisher, H., 2000. Petra: The Restoration of the Rockcut Tomb Facades, Muchen: Bayerisches Landesamt fur Denkmalpfleg Publication. 
Stanley-Price, N., 1997, The Roman Villa at Piazza Armerina, Sicily. In Torre, M., 1997, The conservation of Archaeological Sites in the Mediterranean Region, Los Angeles : The Getty Conservation Institute publication. PP: 65-92.

Russell, K., 1992, The Petra Project, ACOR Newsletter, Vol. 4.1- Summer 1992. PP: 1-2 .

Taylor, J., 2001, Petra and the Lost Kingdom of the Nabataeans, London: I.B Tauris Publishers .

UNESCO Report, 1992. Petra National Park Management Plan, Unpublished report. Coordinators: Lane, B., and Bousquet, B. pp: 1-176.

USAID Jordan, 2001, Fact Sheet Under Royal Patronage The Byzantine Church Officially Opens in the Ancient City of Petra, [On Line]. Available from: http://www.usembassy-

amman.org.jo/USAID/church.htm\{Accessed on 25 June 2000\}.

United State Support for the World Heritage, 2001. Petra.[OnLine].Available from: http://www.usembassyamman.org.jo/USAID/Petra.htm \{Accessed on 18 June 2002\}. 
Viles, H., et al. 1997. Group report. What is the state of our knowledge of the mechanisms of deterioration and how good are estimates of rates of deterioration? In Baer, N. and Snethlage, R., (eds.), 1997. Saving Our Architectural Heritage-The Conservation of Historic Stone Structure. Report of the Dahlem Workshop. Berlin, 3-8 March 1996: John Wiley \& Sons Ltd. pp: 95-112.

Vivekanand, P, 1995, Petra, Amman: Arabesque International Publication .

Zayadine, F., 1986, Recent Excavation \& Restoration at Qasr El Bint of Petra, ADAJ (Annual of the department of Antiquities, Amman- Jordan), Vol. 29. PP: 239-249.

Zayadine, F., 1981, Recent Excavation \& Restoration of the Depatrment of Antuquties (1979- 1980), ADAJ (Annual of the department of Antiquities, AmmanJordan), Vol. 24. PP: 341-355 .

Zayadine, F., and Farajat, S., 1991, The Petra National Trust Site Project: Excavation and Clearance at Petra and Beida, ADAJ (Annual of the department of Antiquities, Amman- Jordan), Vol. 35. PP: 275-311. 